\title{
Consideration of the Dynamic Characteristics of a Planar Parametric Transformer Based on the Mathieu Equation
}

\author{
M. Yoshida, M. Ohta*, M. Natsusaka*, and Y. Sakamoto* \\ Hachinohe National College of Technology, 16-1 Uwanotai, Tamonoki, Hachinohe 039-1192, Japan \\ *Hachinohe Institute of Technology, 88-1 Ohbiraki, Myo, Hachinohe 031-8501, Japan
}

We earlier proposed a planar parametric transformer using a laminated Si-Fe core. In our study, we noticed the Mathieu equation represented the stable state or unstable state of a parametric oscillation. In this paper, (1) the Mathieu equation is obtained for the no-load condition and the load condition, and (2) the relationship between the stable state or unstable state of a parametric oscillation and the operating point of the transformer is clarified. We analyzed these states of a transformer by using MATLAB.

Key words: parametric transformer, parametric oscillation, magnetic circuit model, Mathieu equation, MATLAB.

\section{平面磁路形パラメトリック変圧器の Mathieu 方程式に基づく 動特性に関する考察}

\author{
吉田 雅昭 ·太田 勝* ・夏坂 光男* ・坂本 禎智* \\ 八戸工業高等専門学校，青森県八戸市大字田面木字上野平 16-1 ( 039 -1192) \\ *八戸工業大学，青森県八戸市大字妙字大開 88-1 († 031-8501)
}

1. はじめに

筆者らによって開発された平面磁路形パラメトリック変圧器 ${ }^{1,2)}$ は，構造が簡単であり，過負荷保護機能，雑音ろ波機能，定電圧 特性を有する. パラメトリック発振現象を利用した磁気応用機器 は，その特徴を生かした分野への実用化が期待されているが，磁 心の非線形性によって多くの複雑な問題が発生寸るため, パラメ トリック発振のさらなる安定化のために動作方程式の安定性の考 察は, 設計法確立のために重要である.

また, 筆者らは, これまでに平面磁路形パラメトリック変圧器 の共通磁路部分と磁路狭窄部の磁化特性が磁束の 5 次式としたと き, その動作方程式を導出した. この動作方程式に調波平衡法を 適用し，磁束の振幅と位相の関係を明確にしてきた ${ }^{1,2)}$. 本論文で は，この動作方程式を Mathieu 方程式に置き換え，その解からパ ラメトリック発振の安定性, 不安定性を解析寸る ${ }^{3)}$. その結果, こ の方程式には，動作点を決定するための基本的な Mathieu 方程式 に磁心の磁気飽和による非線形項が加わった形となっていること を明らかにした. この方程式の解析によって, 本変圧器の無負荷 時, 負荷時の動作点が明らかになり, 最適なパラメトリック発振 機器の設計につながる指針を見出すことができた.ここでは，こ れらの検討結果について報告する. なお,この方程式の解析には, 数值解析ソフトである MATLAB を用いた.

\section{2. 平面磁路形パラメトリック変圧器の基本特性}

Fig. 1 は, 試作した平面磁路形パラメトリック変圧器の構成であ る. 巻線数は $N_{1}, N_{2}$ ともに 500 回, 材質は無方向性珪素 鋼板であり, 板厚 $0.35 \mathrm{~mm}$ の鋼板を 50 枚積層した. 本変圧 器は, パラメトリック発振をより生じやすくするために, 上下に 溝を掘った磁路狭窄部を配置し, 励磁側磁路や共振側磁路よりも 共通磁路をさらに狭くした構造としてある. 励磁側巻線で発生し
た磁束は，磁路狭窄部や共通磁路で磁気飽和し，励磁電圧の 1 周 期中に，共振側から見た共通磁路の磁気抵抗が 2 度変化すること によって, 共振側巻線にパラメトリック発振電圧が誘起され, パ ラメトリック発振が生じる 1),2). このとき, 共振側の同調用コンデ ンサの值によって, 出力電圧が定まる.

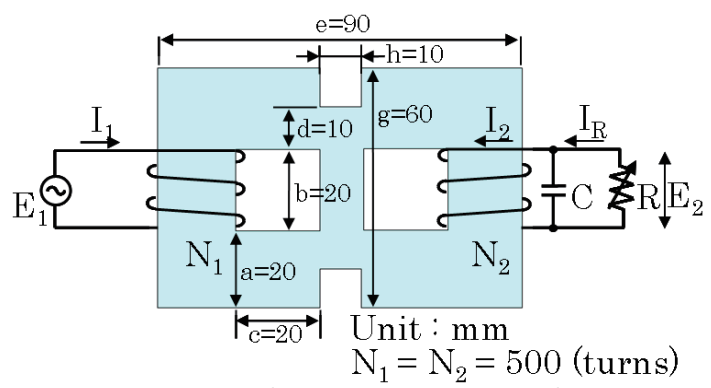

Fig. 1 Outline of the structure of a planar parametric transformer.

Fig. 2 は, 本変圧器の入出力電圧特性である. 同調用コンデン サが, $20 \mu \mathrm{F}$ から $90 \mu \mathrm{F}$ の範囲でパラメトリック発振が生じた. $90 \mu \mathrm{F}$ 以上のコンデンサ容量でも発振が生じるが, 共振側巻 線を流れる電流が許容範囲を超えることから $90 \mu \mathrm{F}$ で実験 を終えた。

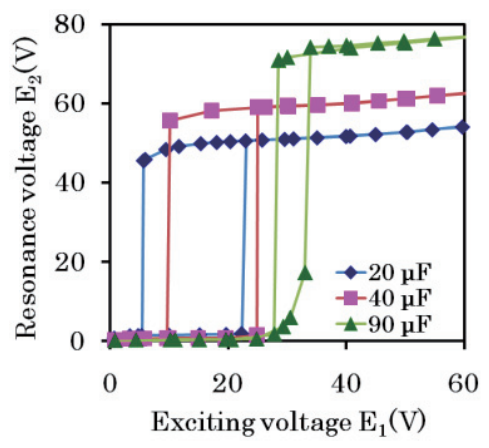

Fig. 2 Exciting voltage vs. resonance voltage in a planar parametric transformer. 
パラメトリック発振が確立する時の励磁電圧と発振が停止する 時の励磁電圧は異なり，ヒステリシスを持つ。これには，磁気飽 和が関係しており, 鋼板の積層枚数が多くなるほど, ヒステリシ スの幅が大きくなる傾向にある.

Fig. 3 は，同調用コンデンサが $40 \mu \mathrm{F}$ のときの負荷特性である. 励磁電圧 $E_{1}$ は, パラメトリック発振確立直後の $25 \mathrm{~V}$, 飽和領域の 始まり付近の $30 \mathrm{~V}, 40 \mathrm{~V}$ そして $50 \mathrm{~V}$ で比較した. 負荷抵抗を減少 させると, 共振電圧 $40 \mathrm{~V}$ 付近をピークに負荷電流が減少している. このことから, 本変圧器は過負荷保護機能を具備していることが わかる。

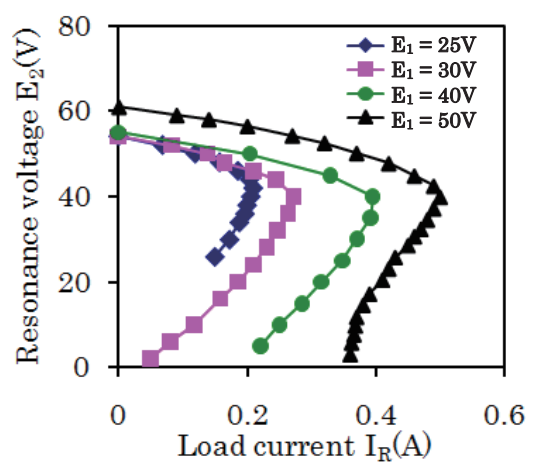

Fig. 3 Load current vs. resonance voltage in a planar parametric transformer $(\mathrm{C}=40 \mu \mathrm{F})$

\section{3. 磁気回路と Mathieu 方程式}

\section{1 無負荷状態における動作方程式の導出}

Fig. 4 は, 本変圧器の磁気回路モデルである. 励磁側および共振 側の磁気抵抗は共に $R_{a}$, 共通磁路の磁気抵抗は $R_{b}$, 中央溝による 磁路狭窄部分の磁気抵抗は $R_{c}$, 励磁側および共振側の磁束は $\phi_{1}$, $\phi_{2}$ とした場合の磁気回路モデルである. ただし, 漏孔磁束は考慮 していない.

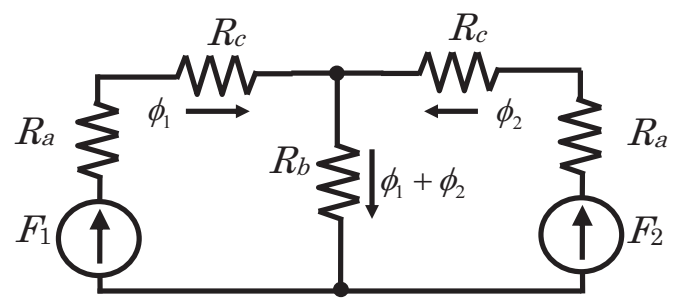

Fig. 4 Magnetic circuit model of a planar parametric transformer.

いま，磁気抵抗 $R_{b}, R_{c}$ の飽和特性を磁束の 5 次式で次のように 表す.

$$
\begin{aligned}
& F_{b}=f_{b}(\phi)=b_{1} \phi+b_{3} \phi^{3}+b_{5} \phi^{5} \\
& F_{c}=f_{c}(\phi)=a_{1} \phi+a_{3} \phi^{3}+a_{5} \phi^{5}
\end{aligned}
$$

磁気抵抗 $R_{a}$ が $R_{b}, R_{c}$ と比べて十分に小さく無視すると, 起磁 力 $F_{1}, F_{2}$ は次のように表すことができる1).

$$
\begin{aligned}
& F_{1}=N_{1} i_{1}=f_{c}\left(\phi_{1}\right)+f_{b}\left(\phi_{1}+\phi_{2}\right) \\
& F_{2}=N_{2} i_{2}=f_{c}\left(\phi_{2}\right)+f_{b}\left(\phi_{1}+\phi_{2}\right)
\end{aligned}
$$

Fig. 5 は, 負荷抵抗を考慮した本変圧器の電気回路であり, 共振 側巻線抵抗は $r_{2}$, 負荷抵抗は $R$ である.

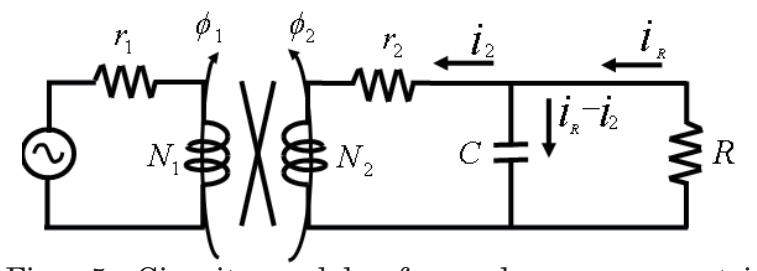

Fig. 5 Circuit model of a planar parametric transformer taking account of the load resistance.

この回路から次式が得られる.

$$
N_{2} \frac{d^{2} \phi_{2}}{d t^{2}}+\frac{N_{2}}{C R} \frac{d \phi_{2}}{d t}+r_{2} \frac{d i_{2}}{d t}+\left(\frac{r_{2}}{C R}+\frac{1}{C}\right) i_{2}=0
$$

ここで，共振側巻線抵抗 $r_{2}$ は無視し 3$)$ ，負荷抵抗 $R$ は無限大， 励磁則磁束 $\phi_{1}$ は振幅 $\phi_{1 \mathrm{~m}}$ と角周波数 $\omega$ を用いて, $\phi_{1}=\phi_{1 \mathrm{~m} \sin } z, Z$ $=\omega t$ と定義すると, (5)式は,(6)式に整理される.ただし， $\phi_{1 \mathrm{~m}}$ は励 磁電土 $E_{1}$, 励磁側巻線数 $N_{1}$ を用いて, $\phi_{1 \mathrm{~m}}=\frac{\sqrt{2} E_{1}}{\omega N_{1}}$ と表される.

$$
\begin{aligned}
& \frac{d^{2} \phi_{2}}{d z^{2}}+(a-2 q \cos 2 z+k \cos 4 z) \phi_{2} \\
& +A_{1}+A_{2}+A_{3}+A_{4}+A_{5}+A_{6}+A_{7}+A_{8}+A_{9}=0
\end{aligned}
$$

各項の内容は, 次のようになる. 基本的な Mathieu 方程式の $\phi_{2}$ の項に関わる係数 $a, 2 q, k$ は,

$$
\begin{aligned}
a & =\frac{1}{\omega^{2} N_{2}^{2} C}\left(a_{1}+b_{1}+\frac{3}{2} b_{3} \phi_{1 m}^{2}+\frac{15}{8} b_{5} \phi_{1 m}^{4}\right) \\
2 q & =\frac{1}{\omega^{2} N_{2}^{2} C}\left(\frac{3}{2} b_{3} \phi_{1 m}^{2}+\frac{5}{2} b_{5} \phi_{1 m}^{4}\right) \\
k & =\frac{5}{8 \omega^{2} N_{2}^{2} C} b_{5} \phi_{1 m}^{4}
\end{aligned}
$$

となる. $A_{1}, A_{2}, A_{3}, A_{4}, A_{5}, A_{6}, A_{7}, A_{8}, A_{9}$ は非線 形項であり, 次のように表される.

$$
\begin{aligned}
& A_{1}=\frac{3}{\omega^{2} N_{2}^{2} C} b_{3} \phi_{1} \phi_{2}^{2} \\
& A_{2}=\frac{10}{\omega^{2} N_{2}^{2} C} b_{5} \phi_{1}^{3} \phi_{2}^{2} \\
& A_{3}=\frac{10}{\omega^{2} N_{2}^{2} C} b_{5} \phi_{1}^{2} \phi_{2}^{3} \\
& A_{4}=\frac{5}{\omega^{2} N_{2}^{2} C} b_{5} \phi_{1} \phi_{2}^{4} \\
& A_{5}=\frac{1}{\omega^{2} N_{2}^{2} C}\left(a_{3}+b_{3}\right) \phi_{2}^{3} \\
& A_{6}=\frac{1}{\omega^{2} N_{2}^{2} C}\left(a_{5}+b_{5}\right) \phi_{2}^{5} \\
& A_{7}=\frac{1}{\omega^{2} N_{2}^{2} C} b_{1} \phi_{1} \\
& A_{8}=\frac{1}{\omega^{2} N_{2}^{2} C} b_{3} \phi_{1}^{3}
\end{aligned}
$$




$$
A_{9}=\frac{1}{\omega^{2} N_{2}^{2} C} b_{5} \phi_{1}^{5}
$$

以上のように, 本変圧器の動作方程式は, 基本的な Mathieu 方 程式に $A_{1}$ から $A_{9}$ までの非線形項が含まれる.

$\phi_{2}$ の初期值は極小のため， $\phi_{2}$ の 3 乗，5 乗に基づく非線形項 $A_{5}, A_{6}$ については解析において無視できる ${ }^{4)}$. また, 無負荷時に おいて， $\phi_{1}$ の 1 乗，3 乗，5乗に基づく非線形項 $A_{7}, A_{8}, A_{9}$ は, 次のように考える. 2 章の Fig. 2 の入出力電圧特性で, 励磁電圧お よび共振電圧が 0 から $80 \mathrm{~V}$ まで変化したとしても， $\phi_{1}$ および $\phi_{2}$ は, $\phi=\frac{E}{4.44 f N}$ で $10^{-4} \mathrm{~Wb}$ 以下となる. よって, 各非線形項は極小 となり，無視できる 5),6)ものとした。 その他の項については， Mathieu 方程式の安定・不安定領域に変化を与えるものと思われ, 今後検討を要する.

\section{2 負荷状態における動作方程式の導出}

ここで，(1)，(2)，(4)式を(5)式に代入し，整理する.

$$
\begin{aligned}
& \frac{d^{2} \phi_{2}}{d z^{2}}+\left(a^{\prime}-2 q^{\prime} \cos 2 z+k^{\prime} \cos 4 z\right) \phi_{2} \\
& +\frac{1}{\omega C R} \frac{d \phi_{2}}{d z}+A_{1}{ }^{\prime}+A_{2}{ }^{\prime}+A_{3}{ }^{\prime}+A_{4}{ }^{\prime}+A_{5}{ }^{\prime}+A_{6}{ }^{\prime}+A_{7}{ }^{\prime}+A_{8}{ }^{\prime}+A_{9}{ }^{\prime}=0
\end{aligned}
$$

各項の内容は次のようになり,$d \phi_{2} d z$ の項（以下減衰項と称す る)が付加された式となり, $\phi_{2}$ の項に関わる係数 $a^{\prime}, 2 q^{\prime}, k^{\prime}$ は,

$$
\begin{aligned}
& a^{\prime}=\frac{1}{\omega^{2} N_{2}^{2} C}\left(\frac{r_{2}}{R}+1\right)\left(a_{1}+b_{1}\right) \\
& +\frac{b_{3}}{2} \phi_{1 m}^{2} \sqrt{\left(\frac{6 r_{2}}{\omega N_{2}^{2}}\right)^{2}+\left\{\frac{3}{\omega^{2} N_{2}^{2} C}\left(\frac{r_{2}}{R}+1\right)\right\}^{2}} \\
& +\frac{3}{8} b_{5} \phi_{1 m}^{4} \sqrt{\left(\frac{20 r_{2}}{\omega N_{2}^{2}}\right)^{2}+\left\{\frac{5}{\omega^{2} N_{2}^{2} C}\left(\frac{r_{2}}{R}+1\right)\right\}^{2}} \\
& 2 q^{\prime}=\frac{\phi_{1 m}^{2}}{2}\left[b_{3} \sqrt{\left(\frac{6 r_{2}}{\omega N_{2}^{2}}\right)^{2}+\left\{\frac{3}{\omega^{2} N_{2}^{2} C}\left(\frac{r_{2}}{R}+1\right)\right\}^{2}}\right. \\
& +b_{5} \phi_{1 m}^{2} \sqrt{\left(\frac{20 r_{2}}{\omega N_{2}^{2}}\right)^{2}+\left\{\frac{5}{\omega^{2} N_{2}^{2} C}\left(\frac{r_{2}}{R}+1\right)\right\}^{2}} \\
& k^{\prime}=\frac{b_{5} \phi_{1 m}^{4}}{8} \sqrt{\left(\frac{20 r_{2}}{\omega N_{2}^{2}}\right)^{2}+\left\{\frac{5}{\omega^{2} N_{2}^{2} C}\left(\frac{r_{2}}{R}+1\right)\right\}^{2}}
\end{aligned}
$$

となる. $A_{1}{ }^{\prime}, A_{2}{ }^{\prime}, A_{3}{ }^{\prime}, A_{4}{ }^{\prime}, A_{5}{ }^{\prime}, A_{6}{ }^{\prime}, A_{7}{ }^{\prime}, A_{8}{ }^{\prime}, A_{9}{ }^{\prime}$ は, 次のように表される.

$$
\begin{aligned}
& A_{1}{ }^{\prime}=\frac{1}{\omega^{2} N_{2}^{2} C}\left(\frac{r_{2}}{R}+1\right) 3 b_{3} \phi_{1} \phi_{2}^{2} \\
& A_{2}{ }^{\prime}=\sqrt{\left(\frac{30 r_{2}}{\omega N_{2}^{2}}\right)^{2}+\left\{\frac{10}{\omega^{2} N_{2}^{2} C}\left(\frac{r_{2}}{R}+1\right)\right\}^{2}} b_{5} \phi_{1}^{3} \phi_{2}^{2} \\
& A_{3}{ }^{\prime}=\sqrt{\left(\frac{20 r_{2}}{\omega N_{2}^{2}}\right)^{2}+\left\{\frac{10}{\omega^{2} N_{2}^{2} C}\left(\frac{r_{2}}{R}+1\right)\right\}_{5}^{2}} b_{5} \phi_{1}^{2} \phi_{2}^{3}
\end{aligned}
$$

$$
\begin{aligned}
& A_{4}{ }^{\prime}=\sqrt{\left(\frac{5 r_{2}}{\omega N_{2}^{2}}\right)^{2}+\left\{\frac{5}{\omega^{2} N_{2}^{2} C}\left(\frac{r_{2}}{R}+1\right)\right\}^{2}} b_{5} \phi_{1} \phi_{2}^{4} \\
& A_{5}{ }^{\prime}=\frac{1}{\omega^{2} N_{2}^{2} C}\left(\frac{r_{2}}{R}+1\right)\left(a_{3}+b_{3}\right) \phi_{2}^{3} \\
& A_{6}{ }^{\prime}=\frac{1}{\omega^{2} N_{2}^{2} C}\left(\frac{r_{2}}{R}+1\right)\left(a_{5}+b_{5}\right) \phi_{2}^{5} \\
& A_{7}{ }^{\prime}=\sqrt{\left(\frac{r_{2}}{\omega N_{2}^{2}}\right)^{2}+\left\{\frac{1}{\omega N_{2}^{2} C}\left(\frac{r_{2}}{R}+1\right)\right\}^{2}} b_{1} \phi_{1} \\
& A_{8}{ }^{\prime}=\sqrt{\left(\frac{3 r_{2}}{\omega N_{2}^{2}}\right)^{2}+\left\{\frac{1}{\omega^{2} N_{2}^{2} C}\left(\frac{r_{2}}{R}+1\right)\right\}^{2}} b_{3} \phi_{1}^{3} \\
& A_{9}{ }^{\prime}=\sqrt{\left(\frac{5 r_{2}}{\omega N_{2}^{2}}\right)^{2}+\left\{\frac{1}{\omega^{2} N_{2}^{2} C}\left(\frac{r_{2}}{R}+1\right)\right\}_{5}^{2}} b_{5} \phi_{1}^{5}
\end{aligned}
$$

なお，非線形項 $A_{5}{ }^{\prime}, A_{6}{ }^{\prime}, A_{7}{ }^{\prime}, A_{8}{ }^{\prime}, A_{9}{ }^{\prime}$ に関しては, 3.1 節と同様な理由により無視できる. その他の項については，今後 検討を要する.

\section{$3.3 \cos 4 z$ に関する検討}

非線形項を考慮した場合の Mathieu 方程式は，無負荷時を(6) 式, 負荷時を(19)式のように表し, (9)式, (22)式から， $k$ および $k^{\prime}$ を算出すると次のような結果が得られる ${ }^{7}$.

$$
\begin{aligned}
& k=3.915 \times 10^{-4} \\
& k^{\prime}=3.955 \times 10^{-4}
\end{aligned}
$$

$$
\begin{aligned}
& \text { ただし, } \\
& \begin{array}{l}
\omega=2 \pi f \mathrm{rad} / \mathrm{s} \quad f=50 \mathrm{~Hz} \quad C_{2}=100 \mu \mathrm{F} \\
N_{2}=500 \text { turns } \quad \phi_{1 \mathrm{~m}}=10 /\left(4.44 \times f \times N_{2}\right) \mathrm{Wb} \\
b_{5}:\left(a_{5}+b_{5}\right) / 2=\left(4.6934 \times 10^{19}\right) / 2 \mathrm{~A} / \mathrm{Wb}^{5}
\end{array}
\end{aligned}
$$

よって， $k$ および $k^{\prime}$ は非常に小さい值となるので, (6)式, (19) 式の $\cos 4 z$ の項は, 無視して解析を行う. なお, $b_{5}$ は, 磁心の磁化 特性から求めた近似係数であり, その詳細については, 4.1 節で述 ベる.

\section{4. 動作点に関する検討}

2 章で述べた入出力電圧特性と負荷特性から, 本変圧器の動作領 域は, 励磁電圧, 同調用コンデンサを設定することによって決定 できる. パラメトリック発振の安定・不安定性は, 磁気回路と電 気回路から求めた本変圧器固有の Mathieu 方程式の $a, q$ の相関 関係で表すことができる. よって, 動作点とパラメトリック発振 の安定・不安定性について検討寸ることは, 本変圧器の特徴を積 極的に利用し, 本変圧器の動作安定と最適設計にもつながるため 非常に重要である.ここでは, 本変圧器の動作点の励磁電圧依存 性について，無負荷時，負荷時についてそれぞれ解析し，検討を 
行うこととする.

\section{1 動作点の励磁電圧依存性について（無負荷時）}

Fig. 7 は, Fig. 1 の寸法形状で, 励磁電圧を $10 \mathrm{~V}$ から $50 \mathrm{~V}$ まで変化させたときの動作点の軌跡である．ここで，同調 用コンデンサは $40 \mu \mathrm{F}$ とした， $a, q$ の值は，(7)式，(8)式 を用いて計算した。動作点は, 同図に示寸ように直線上を 動くことが明らかになった。同図に(6)式から求めた解の安 定・不安定図も重敞た。ここで, 解の安定・不安定図は, パラメトリック発振の安定・不安定性を示す．（6)式の非線 形項は簡単のため省略した。安定性の判定は, 時間変数 $z$ を 0 から 100 まで変化させ， $\phi_{2}$ の安定限界值に対して，1\%を収束と して行っている. 黒点で表した領域が安定(収束), 空白で表した領 域が不安定(発散)である. パラメトリック発振が生じる領域は空白 の領域である.ここで, 安定・不安定図と動作点の関倸に注目寸 る. 励磁電圧が $40 \mathrm{~V}$ の場合, 動作点は黒点と空白領域の境界にあ る.これは, パラメトリック発振が安定と不安定の間にあり，発 振が停止しつつあることを示している. 励滋電土が $50 \mathrm{~V}$ の場合, 動作点は空白領域にある。これは, パラメトリック発振が不安定 になり，発振が生じることを示している。

\section{Stability chart of the Mathieu equation}

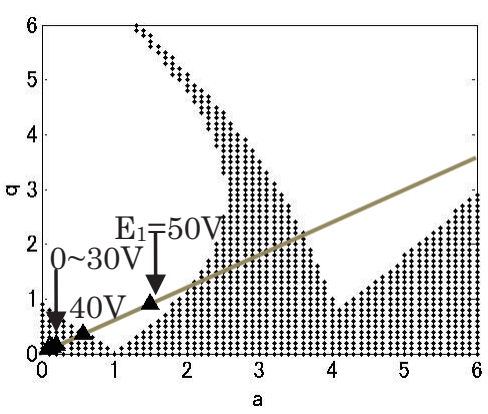

Fig. 7 Exciting voltage dependence of the operating point (in the no-load condition) .

解析において, 式中の $a_{1}, b_{1}, b_{3}, b_{5}$ は, 磁心の磁化特 性から求めた $a_{1}+b_{1}=1.3453 \times 10^{5} \mathrm{~A} / \mathrm{Wb}, a_{3}+b_{3}=-$ $3.2809 \times 10^{12} \mathrm{~A} / \mathrm{Wb}^{3}, \quad a_{5}+b_{5}=4.6934 \times 10^{19} \mathrm{~A} / \mathrm{Wb}^{5}$ 7) より $a_{1}=$ $b_{1}, a_{3}=b_{3}, a_{5}=b_{5}$, として, 平均值を代入したものである. これは, 磁路狭窄部の磁気抵抗 $R$, , 共通磁路の磁気抵抗 $R b$ が非線形で, 同一の磁化特性であると仮定した結果である. しかし, 実際には, 各近似係数の和が一定であっても, 例 えば， $a_{1}$ と $b_{1}$ の場合には，どちらかに偏りがあることが考 えられる.このことについて(7)式，(8)式を用いてさらに考 えてみる.これらの式には， $a_{1}, b_{1}, b_{3}, b_{5}$ が付加されてお り, 磁路狭窄部 $R_{c}$ よりも共通磁路 $R_{b}$ の磁気抵抗による影 響が大きいと考えられ，さらに， $R_{b}$ が線形である場合は， $b_{3}=0, b_{5}=0$ となり，(8)式は 0 となるので，パラメトリッ ク発振は絶対に生じない. 共通磁路 $R_{b}$ はパラメトリック発 振を生じさせるために重要かつ必要であるため, Fig. 8 の ような磁路狭窄部がない場合 $\left(R_{c}\right.$ がない場合 $)$ の形状につい てもさらに検討することにした. Fig. 8 のような形状では, 上記の近似係数 $a_{3}, a_{5}$ の項は 0 となり, $b_{3}, b_{5}$ の項に近似
係数の全ての值が代入されることになるので，共通磁路の 磁気抵抗 $R_{b}$ の影響が最大となる.

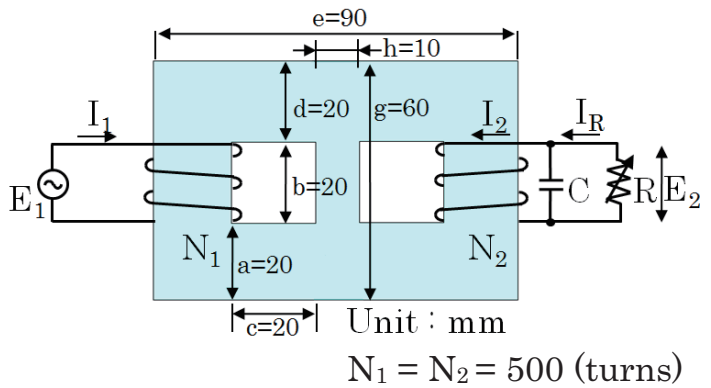

Fig. 8 Outline of the structure of the transformer without $R c$ (in the no-load condition).

Fig. 9 は，この場合の動作点の解析結果である.ここで も，同調用コンデンサは $40 \mu \mathrm{F}$ とした。これを見ると，動 作点の軌跡は直線となり，Fig. 7 とほぼ同一の軌道にある ことが分かった。磁路狭窄部の溝がなくなると動作点は直 線の上方に推移し, 発振が生じない領域に移動する場合も あることが明確になった．具体的に見ると，Fig. 7 は励磁 電圧 50V, Fig. 9 は励磁電圧 $40 \mathrm{~V}$ においてパラメトリック 発振が生じる不安定領域（空白領域）にあり，さらに，Fig. 9 は励磁電圧 $50 \mathrm{~V}$ で, パラメトリック発振が生じない安定 領域（黒点領域）にある。したがって, 励磁電圧, 同調用 コンデンサの值, 変圧器の寸法形状が変化し, 安定・不安 定領域も変化することから, これらは変圧器の設計指針の 一つとなることが理解できる.

なお，現段階では，Fig. 8 における形状での実験は行っ ておらず, 今後, 試作し, 検討していく予定である.

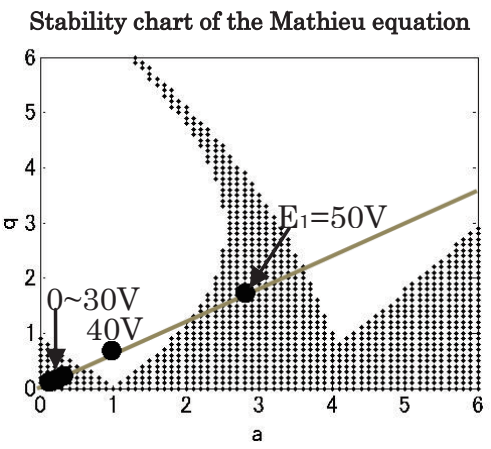

Fig. 9 Exciting voltage dependence of the operating point in the transformer without $R c$ (in the no-load condition) .

\section{2 動作点の励磁電圧依存性について（負荷時）}

Fig. 10 は, 負荷時における動作点の励磁電圧依存性であ る.ここでも，同調用コンデンサは $40 \mu \mathrm{F}$ とし，(19)式の非 線形項は簡単のため省略した。ここで, 同図 $a=1$ の○印に 注目する. Fig. 10 と無負荷時の Fig. 7 および Fig. 9 の違 いは, パラメトリック発振の安定領域（黒点領域）が $q$ 軸 方向に移動していることにある。これは，(19)式の減衰項 によって生じている。また，Fig. 10 では，(20)式，(21)式 
を用いて， $a, q$ の值が求められる. Fig. 1 と Fig. 8 の動作 点は，それぞれ $\boldsymbol{\Delta}$, ○であり, 励磁電圧が低い場合は, 動 作点が原点付近に集中する，負荷時は，無負荷時とほぼ同 様の直線関係となる.この安定領域が, 変圧器の動作線に 接近すると, 動作線直下の空白領域は狭くなる。これは, 負荷時で，パラメトリック発振の生じる領域が，減衰項の 影響によって，制限されることを意味する，よって，パラ メトリック発振の安定・不安定領域のみが変化することが 明確になった。 なお, 今後は, 3.2 節で求めた非線形項 $A_{1}$ から $A_{4}$ までの影響を考慮したパラメトリック発振の安定・不安 定領域について検討する必要がある。これにより, 詳細な 設計指針が確立され, 本変圧器のさらなる安定化が実現す ると考えられる.

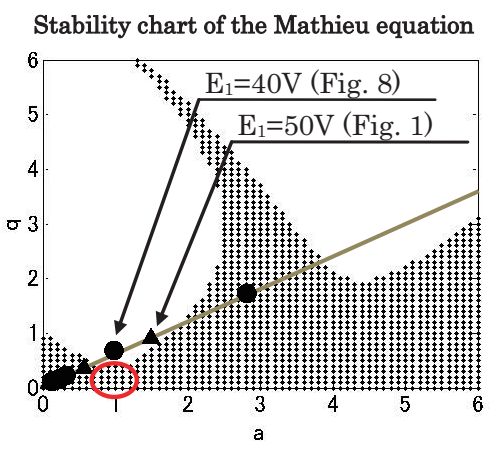

Fig. 10 Exciting voltage dependence of the operating point (in the load condition).

\section{3 安定 - 不安定領域と負荷特性の対応}

Fig. 11 は, 励磁電圧 $50 \mathrm{~V}$, 同調用コンデンサ $40 \mu \mathrm{F}$ にお ける負荷特性から, 負荷抵抗 $R$ を算出した結果である.

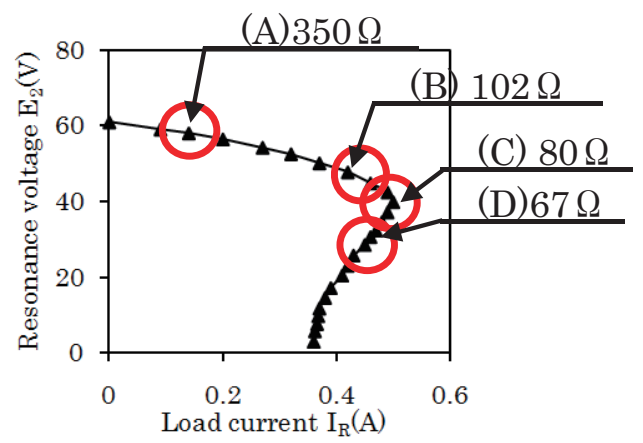

Fig. 11. Load characteristic and estimated value of load resistance.

Fig. 12 は，同調用コンデンサ $40 \mu \mathrm{F}$ の条件で，（19)式を 用い, Fig. 11 で見積もった $R$ を代入し, 解析した結果であ る.また，同図は，Fig. 10 の，qの領域を拡大したもの で, Fig. 1 の形状で励磁電圧 50V の動作点を $\Delta$, Fig. 8 の 形状で励磁電圧 $40 \mathrm{~V}$ の動作点を○で表した. ここで, Fig. 12(a)は, Fig. 11(A)の負荷電流増加の領域に対応し, $\boldsymbol{\Delta}$ と

○は共に, 空白領域にあるので, パラメトリック発振が生

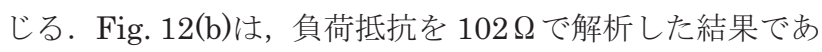
る.ムは黒点領域に接し，○は黒点領域に覆われるので，
は発振が停止しつつあり， は発振停止となる。さらに， Fig. 12(c)と (d)は， $\boldsymbol{\Delta}$ とは共に黒点領域に覆われるので, 発振停止となる. よって, 励磁電圧や同調用コンデンサの 電気的諸条件, 磁路狭窄部の寸法形状, 磁心の材料で決定 された動作点は直線関係になり, 負荷時の Mathieu 方程式 から求めたパラメトリック発振の安定・不安定領域は，負 荷抵抗の変化によって, $q$ 軸方向に移動することが理解で きる，したがって，実験結果と解析結果の良好な一致は， 本研究の妥当性を示し, 動作点と発振の安定・不安定図と の関係は, 本変圧器の動作安定と最適設計につながること も示す.
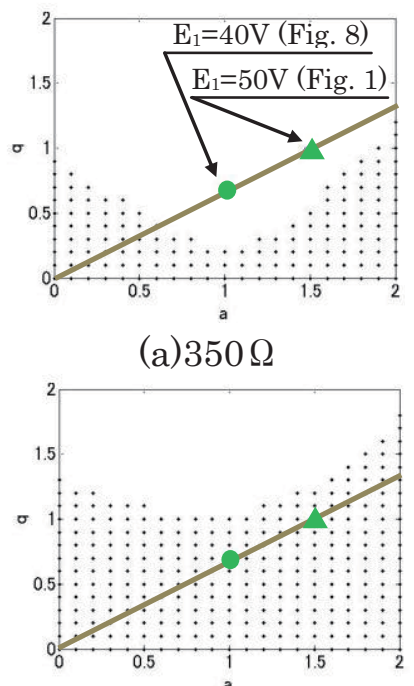

(c) $80 \Omega$ (a) $350 \Omega$

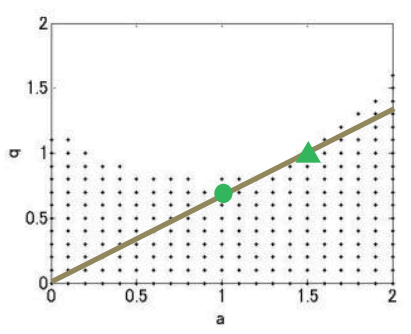

(b) $102 \Omega$

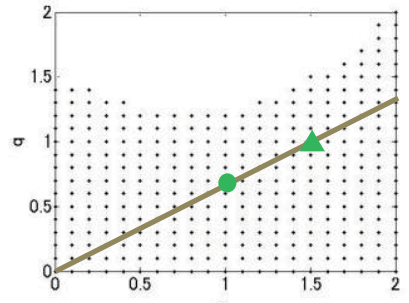

(d) $67 \Omega$
Fig. 12. Correspondence of stable and unstable regions and load resistance.

\section{5. まとめ}

平面磁路形パラメトリック変圧器の無負荷時，負荷時における Mathieu 方程式を導出し, その動作点とパラメトリック発振の安 定性について考察した結果，次のことが明確になった。

(1) 本変圧器の Mathieu 方程式は, 通常の Mathieu 方程式に はならず, $k \cos 4 z \phi_{2}$ の項が含まれる. 無負荷時の $k$ および負荷時 の $k^{\prime}$ は, $10^{-4}$ オーダーとなり, パラメトリック発振の安定・不安 定領域への影響がない.

（2）本変圧器の動作点は, 励磁電圧, 同調用コンデンサの電気 的諸条件, 磁路狭窄部の寸法形状, 磁心の材料で決定される近似 係数によって定まり, 無負荷時, 負荷時での変化がなく直線関係 になる.

（3）負荷時の Mathieu 方程式には, 減衰項が付加され, この減 衰項によって, パラメトリック発振の安定・不安定性が変化する.

本論文の結果は, 今後の変圧器の設計に役立つ有用な成果と考 えられる. 


\section{Reference}

1) M. Ohta, Y. Sakamoto, M. Natsusaka, and K. Murakami: J. Magn. Soc. Japan, 22, 4, pp. 717-720 (1998)

2) M. Ohta, Y. Sakamoto, and K. Murakami: J. Magn. Soc. Japan, 23, 4, pp. 1501-1504 (1999)

3) Y. Sakamoto, M. Natsusaka, and M. Ohta: T. IEE Japan, MAG-01-67 (2001)

4) E. S. Tez and I. R. SMITH: IEEE Trans. Magn., E-27, 2, pp. 56-65 (1984)

5) M. Ara, M. Ohta, M. Natsusaka, and Y. Sakamoto:T. IEE Japan, MAG-07-17(2007)

6) M. Ara, M. Ohta, M. Natsusaka and Y. Sakamoto: J. Magn. Soc. Japan, 32, 3, pp. 396-404 (2008)

7) M. Yoshida, M. Ohta, M. Natsusaka and Y. Sakamoto: $T$. IEE Japan, MAG-09-35 (2009)

2009 年 10 月 20 日受理, 2010 年 1 月 21 日再受理, 2010 年 3 月 17 日採録 